\title{
Evaluation of safety profile of the essential oils of eight Heracleum taxa (Apiaceae) related to determined furanocoumarin content
}

\section{Ljuboš Ušjak $^{1^{*}}$, Milica Drobac ${ }^{1}$, Marjan Niketić ${ }^{2}$, Silvana Petrović $^{1}$}

${ }^{1}$ University of Belgrade - Faculty of Pharmacy, Department of Pharmacognosy, Vojvode Stepe 450, 11221 Belgrade, Serbia

${ }^{2}$ Natural History Museum, Njegoševa 51, 11000 Belgrade, Serbia

"Corresponding author. Ljuboš Ušjak, Tel.: +381 1139513 22,

e-mail: 1jubos@pharmacy.bg.ac.rs

\section{Summary}

For essential oils of roots, leaves, flowers and fruits of eight Heracleum taxa (H. sphondylium, H. sibiricum, H. montanum, H. ternatum, H. pyrenaicum subsp. pollinianum, $H$. pyrenaicum subsp. orsinii, $H$. verticillatum and $H$. orphanidis), we previously demonstrated antimicrobial, cytotoxic (selective to cancer cells) and/or antioxidant activities. In this work, for these essential oils maximum daily intake related to total furanocoumarins (FCs) content was estimated, according to Committee on Herbal Medicinal Products of European Medicines Agency (EMA/HMPC) recommendations. FCs were quantified using gas chromatography, and their sum equivalent to xanthotoxin (8-methoxypsoralen, 8-MOP) was calculated. It was shown that daily intake, not contributing significantly to overall risk (equivalent to intake of $1.5 \mathrm{mg}$ FCs) for root essential oils was in the range of 1.94-5.23 mL, for fruit oils of 5.23-15.68 mL and for leaf or flower oils of 2.90-15.68 mL. Daily intake, not posing any unacceptable risk (equivalent to intake of $15 \mu \mathrm{g} F C s$ ) for root oils was in the range of $0.02-0.05 \mathrm{~mL}$, for fruit oils of $0.05-0.16 \mathrm{~mL}$ and for leaf or flower oils of $0.03-0.16 \mathrm{~mL}$. This work demonstrates the application of current EMA/HMPC recommendations, in order to establish safety profile of herbal preparations containing FCs.

Keywords: Heracleum, essential oils, furanocoumarins, 8-MOP, safety profile 


\section{Introduction}

The genus Heracleum L. is among the largest ones in the Apiaceae family, with more than 120 taxa distributed mainly in Eurasia, where these plants are occasionally used in traditional medicine and/or as food (1). In the Balkan Peninsula, the infusion prepared from roots, leaves or fruits, powdered roots or leaf juice from common cow parsnip („mečja šapa” in Serbian), H. sphondylium L. and related species were traditionally used to treat digestive disorders, epilepsy, hypertension, respiratory infections and inflammations, skin infections, sexual weakness etc. (2). In addition, the consumption of the roots, and young leaves and stems of H. sphondylium, H. sibiricum L. and $H$. pyrenaicum Lam. is suggested in some survival handbooks (3).

In the focus of this study are eight representatives of the type section of the genus (H. sect. Heracleum), seven belonging to the H. sphondylium group (H. sphondylium, $H$. sibiricum, H. montanum Schleich. ex Gaudin, H. ternatum Velen., H. pyrenaicum subsp. pollinianum (Bertol.) F. Pedrotti \& Pignatti, H. pyrenaicum subsp. orsinii (Guss.) F. Pedrotti \& Pignatti and H. verticillatum Pančić), as well as H. orphanidis Boiss. For the purpose of our research, the plants were collected in Southeastern Europe (Serbia, Montenegro, North Macedonia and Slovenia), however, most of them are also native in some other parts of Europe, except $H$. verticillatum and $H$. orphanidis, which are endemic species of central Balkan $(4,5)$. In previous researches, we analyzed the chemical composition of essential oils of different organs of these plants by GC-FID and GC-MS, and demonstrated their antimicrobial, cytotoxic (selective to cancer cell lines) and/or antioxidant activities (6-12).

Furanocoumarins (FCs) are present in certain amounts in many Apiaceae plants, including some vegetables (e.g. parsnip, Pastinaca sativa L., celery, Apium graveolens L., and parsley, Petroselinum crispum (Mill.) Fuss), as well as in the fruits from the Rutaceae family (e.g. lime, Citrus aurantiifolia (Christm.) Swingle and grapefruit, Citrus paradisi Macfad.) $(13,14)$. FCs are known as photosensibilizing agents. Some of them, e.g. xanthotoxin (8-methoxypsoralen, 8-MOP) and bergapten (5methoxypsoralen, 5-MOP), are used in combination with UVA radiation, in PUVA therapy of severe vitiligo and psoriasis. In higher concentrations, FCs can cause acute skin reactions (photodermatitis), mainly manifested as pigmentation, erythema, itching and blisters $(1,15)$. Also, several cohort and case-control studies led to conclusion that PUVA therapy can cause squamous cell skin cancer in a dose- and time-dependent manner (15). For example, in a study of Hannuksela-Svahn et al. (16), the number of patients needed to be treated with PUVA to result in one extra case of this type of skin cancer was 3030. Therefore, the Committee on Herbal Medicinal Products (HMPC) of the European Medicines Agency (EMA) issued the document on the risks associated with FCs contained in preparations of angelica, Angelica archangelica L. (Apiaceae), in which maximum daily intake of FCs through herbal medicinal products is given. Daily 
exposure of $1.5 \mathrm{mg}$ FCs expressed as 8-MOP through herbal medicinal products is not considered to contribute significantly to overall risk, and the intake of $15 \mu \mathrm{g}$ is not considered to pose any unacceptable risk to consumers (15).

Thus, the aim of this work was to quantify FCs in Heracleum essential oils using external standard method, to calculate total FCs equivalent to 8-MOP and estimate maximum daily intake of investigated oils, according to current EMA/HMPC recommendations.

\section{Experimental}

\section{Furanocoumarin (FC) standards}

Commercial standards of xanthotoxin (8-MOP, purity $\geq 98 \%$ ), bergapten (5-MOP, $\geq 99 \%$ ) and isopimpinellin ( $\geq 95 \%$ ) were obtained from Sigma-Aldrich (USA).

\section{Heracleum essential oils}

From roots, leaves, flowers and fruits of eight investigated Heracleum taxa (localities and years of collection are integrated in Table II), essential oils were isolated by hydrodistillation in Clevenger-type apparatus for $2.5 \mathrm{~h}$. The essential oil yields, as well as the relative percentages of essential oils compounds, determined by GC-FID and GC-MS, were previously published. Besides different monoterpenes, sesquiterpenes, phenylpropanoids and/or aliphatic esters, in 32 out of 56 analyzed essential oils, small amounts (up to $0.8 \%$ ) of FCs were detected (6-12). In this work, the quantities of FCs were determined by the external standard method.

\section{Quantifications of FCs by external standard method and calculation of the sum of FCs equivalent to 8-MOP}

FCs in Heracleum essential oils were analyzed on an Agilent 6890N Gas Chromatograph equipped with a split/splitless injector $\left(200^{\circ} \mathrm{C}\right)$, a FID detector and an Agilent HP-5MS capillary column $(30 \mathrm{~m} \times 0.25 \mathrm{~mm}, 0.25 \mu \mathrm{m}$ film thickness $)$, and coupled with an Agilent 5975C mass selective detector (MSD), operating in the EI mode at $70 \mathrm{eV}$. The FID and MSD transfer line temperatures were 300 and $250{ }^{\circ} \mathrm{C}$, respectively. The carrier gas was $\mathrm{He}$, flow $1.0 \mathrm{~mL} / \mathrm{min}$. The oven temperature was programmed linearly, increasing from 60 to $280{ }^{\circ} \mathrm{C}$ at $3{ }^{\circ} \mathrm{C} / \mathrm{min}$. Split ratio was 1:10. For quantification of bergapten and isobergapten, the calibration curve of bergapten standard was prepared, and in the case of isopimpinellin and pimpinellin, the calibration curve of isopimpinellin standard was used. As proposed by EMA/HMPC (15), the sum of FCs equivalent to 8-MOP was calculated, using the calibration curve of 8-MOP standard. Regression equations, $\mathrm{r}^{2}$, linear ranges, and limits of detection (LOD) and quantification (LOQ) of the FCs are given in Table I. LODs and LOQs were 
determined using the standard deviations of the intercepts $\left(\mathrm{SD}_{\mathrm{b}}\right)$, and the slopes $(\mathrm{a})$, in the following way (17):

$$
\begin{aligned}
& \mathrm{LOD}=3.3 \times \mathrm{SD}_{\mathrm{b}} / \mathrm{a} \\
& \mathrm{LOQ}=10 \times \mathrm{SD}_{\mathrm{b}} / \mathrm{a}
\end{aligned}
$$

In calculation of the sum of FCs equivalent to 8-MOP, LOQ value of 8-MOP $(0.096 \mathrm{mg} / \mathrm{mL})$ was used for those FCs, which content was bellow LOQ of 8-MOP.

Table I Regression equations, $\mathrm{r}^{2}$, linear ranges, and limits of detection (LOD) and quantification (LOQ) of bergapten (5-MOP), isopimpinellin and xanthotoxin (8-MOP)

\begin{tabular}{|llllll|}
\hline Compound & Regression equation & $\begin{array}{l}\text { Linear range } \\
(\mathbf{m g} / \mathbf{m L})\end{array}$ & $\mathbf{r}^{\mathbf{2}}$ & $\begin{array}{l}\text { LOD } \\
(\mathbf{m g} / \mathbf{m L})\end{array}$ & $\begin{array}{l}\text { LOQ } \\
(\mathbf{m g} / \mathbf{m L})\end{array}$ \\
\hline 5-MOP & $\mathrm{y}=886362.4975 \mathrm{x}-11498.5262$ & $0.025-2.0$ & 0.9998 & 0.022 & 0.066 \\
\hline Isopimpinellin & $\mathrm{y}=901889.1029 \mathrm{x}-24658.5002$ & $0.04-1.6$ & 0.9991 & 0.041 & 0.124 \\
\hline 8-MOP & $\mathrm{y}=931332.3162 \mathrm{x}-17221.4947$ & $0.02625-2.1$ & 0.9996 & 0.032 & 0.096 \\
\hline
\end{tabular}

\section{Results}

In this work, maximum daily intake related to determined FCs content of 32 samples of essential oils of different plant organs of eight Heracleum taxa $(H$. sphondylium, $H$. sibiricum, $H$. montanum, $H$. ternatum, $H$. pyrenaicum subsp. pollinianum, $H$. pyrenaicum subsp. orsinii, $H$. verticillatum and $H$. orphanidis) was estimated. In Table II, quantities of individual FCs, the sum of FCs equivalent to 8$\mathrm{MOP}$, and daily intakes that are not considered to contribute significantly to overall risk, as well as to pose any unacceptable risk, according to EMA/HMPC recommendations (15), for investigated essential oil are presented. 
Table II Quantities of individual furanocoumarins (FCs) in investigated Heracleum essential oils $(\mathrm{mg} / \mathrm{mL})$, the sum of FCs equivalent to $8-\mathrm{MOP}(\mathrm{mg} / \mathrm{mL})$, and daily intakes of the oils $\left(\mathrm{V}_{\mathrm{EO}}, \mathrm{mL}\right)$ that are not considered to contribute significantly to overall risk (equivalent to intake of $1.5 \mathrm{mg} \mathrm{FCs}$ ) and to pose any unacceptable risk (equivalent to intake of $15 \mu \mathrm{g} \mathrm{FCs)}$

\begin{tabular}{|c|c|c|c|c|c|c|c|}
\hline \multirow{2}{*}{\begin{tabular}{|l} 
Essential oil (EO) \\
Heracleum taxa/locality/year of collection
\end{tabular}} & \multicolumn{4}{|c|}{ Furanocoumarins $(\mathbf{F C s})^{\mathrm{a}}$} & \multirow{2}{*}{$\begin{array}{l}\text { Sum of } \\
\text { FCs } \\
\text { eq. to } \\
\text { 8-MOP }\end{array}$} & \multirow{2}{*}{$\begin{array}{c}V_{E O} \\
(\mathrm{~mL}) \\
\text { eq. to } \\
1.5 \mathrm{mg} \\
\text { FCs }\end{array}$} & \multirow{2}{*}{$\begin{array}{c}V_{\text {EO }} \\
(\mathrm{mL}) \\
\text { eq. to } \\
15 \mu \mathrm{g} \\
\text { FCs }\end{array}$} \\
\hline & 1 & 2 & 3 & 4 & & & \\
\hline \multicolumn{8}{|l|}{ Roots } \\
\hline H. sphondylium/Litija, Krško (SVN)/2015 & 0.10 & $<\mathrm{LOQ}^{\mathrm{b}}$ & 0.12 & $<$ LOQ & 0.42 & 3.54 & 0.04 \\
\hline H. sibiricum/Niš (SRB)/2011 & 0.24 & 0.11 & 0.31 & $<\mathrm{LOQ}$ & 0.77 & 1.94 & 0.02 \\
\hline H. sibiricum/Niš (SRB)/2013 & 0.15 & 0.09 & 0.17 & $<$ LOQ & 0.53 & 2.85 & 0.03 \\
\hline $\begin{array}{l}\text { H. sibiricum/Žarkova Čuka, Mts Stara Planina } \\
\text { (SRB)/2012 }\end{array}$ & 0.08 & $<\mathrm{LOQ}$ & 0.12 & $<\mathrm{LOQ}$ & 0.41 & 3.62 & 0.04 \\
\hline $\begin{array}{l}\text { H. sibiricum/Arbinje, Mts Stara Planina } \\
\text { (SRB)/2014 }\end{array}$ & $<\mathrm{LOQ}$ & $<\mathrm{LOQ}$ & $<\mathrm{LOQ}$ & n.d. ${ }^{\mathrm{c}}$ & 0.29 & 5.23 & 0.05 \\
\hline $\begin{array}{l}\text { H. montanum/Kamnik-Savinja Alps } \\
(\mathrm{SVN}) / 2015\end{array}$ & 0.14 & $<\mathrm{LOQ}$ & 0.17 & $<$ LOQ & 0.50 & 2.99 & 0.03 \\
\hline H. ternatum/Mt Durmitor (MNE)/2013 & 0.08 & $<\mathrm{LOQ}$ & 0.14 & $<$ LOQ & 0.43 & 3.46 & 0.03 \\
\hline $\begin{array}{l}\text { H. pyrenaicum subsp. pollinianum/Mt Bistra } \\
\text { (MKD)/2010 }\end{array}$ & 0.10 & $<$ LOQ & 0.14 & $<\mathrm{LOQ}$ & 0.44 & 3.38 & 0.03 \\
\hline $\begin{array}{l}\text { H. p. subsp. pollinianum/Mt Galičica } \\
\text { (MKD)/2012 }\end{array}$ & 0.17 & 0.18 & 0.20 & $<\mathrm{LOQ}$ & 0.66 & 2.29 & 0.02 \\
\hline $\begin{array}{l}\text { H. p. subsp. pollinianum/Mt Jablanica } \\
\text { (MKD)/2015 }\end{array}$ & $<\mathrm{LOQ}$ & $<\mathrm{LOQ}$ & $<\mathrm{LOQ}$ & $<\mathrm{LOQ}$ & 0.38 & 3.92 & 0.04 \\
\hline H. p. subsp. orsinii/Mt Durmitor (MNE)/2013 & 0.09 & $<$ LOQ & 0.16 & $<$ LOQ & 0.45 & 3.31 & 0.03 \\
\hline $\begin{array}{l}\text { H. verticillatum/Vražja Glava, Mts St. Planina } \\
\text { (SRB)/2010 }\end{array}$ & 0.16 & 0.10 & 0.38 & $<$ LOQ & 0.76 & 1.99 & 0.02 \\
\hline $\begin{array}{l}\text { H. verticillatum/Arbinje, Mts Stara Planina } \\
\text { (SRB)/2012 }\end{array}$ & 0.08 & $<\mathrm{LOQ}$ & 0.15 & $<$ LOQ & 0.44 & 3.38 & 0.03 \\
\hline $\begin{array}{l}\text { H. verticillatum/Arbinje, Mts Stara Planina } \\
\text { (SRB)/2014 }\end{array}$ & 0.10 & $<\mathrm{LOQ}$ & 0.19 & $<\mathrm{LOQ}$ & 0.49 & 3.07 & 0.03 \\
\hline H. orphanidis/Mt Baba Planina (MKD)/2012 & n.d. & n.d. & 0.40 & $<$ LOQ & 0.53 & 2.83 & 0.03 \\
\hline
\end{tabular}




\begin{tabular}{|c|c|c|c|c|c|c|c|}
\hline \multirow{2}{*}{$\begin{array}{l}\text { Essential oil (EO) } \\
\text { Heracleum taxa/locality/year of collection }\end{array}$} & \multicolumn{4}{|c|}{ Furanocoumarins (FCs) ${ }^{\mathbf{a}}$} & \multirow{2}{*}{$\begin{array}{l}\text { Sum of } \\
\text { FCs } \\
\text { eq. to } \\
\text { 8-MOP }\end{array}$} & \multirow{2}{*}{$\begin{array}{c}V_{E O} \\
(\mathrm{~mL}) \\
\text { eq. to } \\
1.5 \mathrm{mg} \\
\text { FCs }\end{array}$} & \multirow{2}{*}{$\begin{array}{c}V_{\text {EO }} \\
(\mathrm{mL}) \\
\text { eq. to } \\
15 \mu g \\
\text { FCs }\end{array}$} \\
\hline & 1 & 2 & 3 & 4 & & & \\
\hline \multicolumn{8}{|l|}{ Fruits } \\
\hline H. sphondylium/Litija and Krško (SVN)/2015 & n.d. & $<\mathrm{LOQ}$ & n.d. & n.d. & 0.10 & 15.68 & 0.16 \\
\hline H. sibiricum/Niš (SRB)/2011 & n.d. & $<\mathrm{LOQ}$ & $<\mathrm{LOQ}$ & n.d. & 0.19 & 7.84 & 0.08 \\
\hline H. sibiricum/Niš (SRB)/2014 & n.d. & $<\mathrm{LOQ}$ & n.d. & n.d. & 0.10 & 15.68 & 0.16 \\
\hline $\begin{array}{l}\text { H. sibiricum/Žarkova Čuka, Mts Stara Planina } \\
(\mathrm{SRB}) / 2012\end{array}$ & n.d. & $<\mathrm{LOQ}$ & $<\mathrm{LOQ}$ & n.d. & 0.19 & 7.84 & 0.08 \\
\hline $\begin{array}{l}\text { H. sibiricum/Arbinje, Mts Stara Planina } \\
(\mathrm{SRB}) / 2014\end{array}$ & n.d. & $<\mathrm{LOQ}$ & $<\mathrm{LOQ}$ & n.d. & 0.19 & 7.84 & 0.08 \\
\hline $\begin{array}{l}\text { H. montanum/Kamnik-Savinja Alps } \\
(\mathrm{SVN}) / 2015\end{array}$ & n.d. & $<\mathrm{LOQ}$ & n.d. & n.d. & 0.10 & 15.68 & 0.16 \\
\hline H. ternatum/Mt Durmitor (MNE)/2013 & n.d. & $<\mathrm{LOQ}$ & n.d. & n.d. & 0.10 & 15.68 & 0.16 \\
\hline H. ternatum/Mt Durmitor (MNE)/2014 & n.d. & $<\mathrm{LOQ}$ & n.d. & n.d. & 0.10 & 15.68 & 0.16 \\
\hline $\begin{array}{l}\text { H. pyrenaicum subsp. pollinianum/Mt Galičica } \\
\text { (MKD)/2012 }\end{array}$ & $<\mathrm{LOQ}$ & $<\mathrm{LOQ}$ & $<\mathrm{LOQ}$ & n.d. & 0.29 & 5.23 & 0.05 \\
\hline H. p. subsp. orsinii/Mt Durmitor (MNE)/2011 & $<\mathrm{LOQ}$ & $<\mathrm{LOQ}$ & $<\mathrm{LOQ}$ & n.d. & 0.29 & 5.23 & 0.05 \\
\hline H. p. subsp. orsinii/Mt Durmitor (MNE)/2013 & n.d. & $<\mathrm{LOQ}$ & n.d. & n.d. & 0.10 & 15.68 & 0.16 \\
\hline $\begin{array}{l}\text { H. verticillatum/Vražja Glava, Mts St. Planina } \\
(\mathrm{SRB}) / 2010\end{array}$ & $<\mathrm{LOQ}$ & n.d. & 0.16 & n.d. & 0.26 & 5.76 & 0.06 \\
\hline $\begin{array}{l}\text { H. verticillatum/Arbinje, Mts Stara Planina } \\
(\mathrm{SRB}) / 2012\end{array}$ & $<\mathrm{LOQ}$ & $<\mathrm{LOQ}$ & $<\mathrm{LOQ}$ & n.d. & 0.29 & 5.23 & 0.05 \\
\hline $\begin{array}{l}\text { H. verticillatum/Arbinje, Mts Stara Planina } \\
(\mathrm{SRB}) / 2013\end{array}$ & $<\mathrm{LOQ}$ & $<\mathrm{LOQ}$ & $<\mathrm{LOQ}$ & n.d. & 0.29 & 5.23 & 0.05 \\
\hline \multicolumn{8}{|l|}{ Leaves } \\
\hline $\begin{array}{l}\text { H. pyrenaicum subsp. pollinianum/Mt Galičica } \\
(\mathrm{MKD}) / 2012\end{array}$ & n.d. & 0.07 & n.d. & n.d. & 0.10 & 15.68 & 0.16 \\
\hline $\begin{array}{l}\text { H. verticillatum/Arbinje, Mts Stara Planina } \\
(\mathrm{SRB}) / 2014\end{array}$ & $<\mathrm{LOQ}$ & $<\mathrm{LOQ}$ & 0.30 & n.d. & 0.52 & 2.90 & 0.03 \\
\hline Flowers & & & & & & & \\
\hline $\begin{array}{l}\text { H. montanum/Kamnik-Savinja Alps } \\
(\mathrm{SVN}) / 2015\end{array}$ & n.d. & n.d. & $<\mathrm{LOQ}$ & n.d. & 0.10 & 15.68 & 0.16 \\
\hline
\end{tabular}

${ }^{\mathrm{a}}$ FCs: 1 - isobergapten, 2 - bergapten, 3 - pimpinellin, 4 - isopimpinellin. ${ }^{\mathrm{b}} \mathrm{LOQ}$ - limit of quantification: bergapten, isobergapten $<0.07 \mathrm{mg} / \mathrm{mL}$; isopimpinellin, pimpinellin $<0.12 \mathrm{mg} / \mathrm{mL}$. ${ }^{\text {c }}$ n.d. - not detected. SVN Slovenia, SRB - Serbia, MNE - Montenegro, MKD - North Macedonia. 


\section{Root essential oils}

Pimpinellin was detected in all 15 investigated root oils, and it was the dominant FC in 13 of them $(0.12-0.40 \mathrm{mg} / \mathrm{mL})$, while in remaining two, all detected FCs were present in quantities bellow LOQ. Isobergapten, bergapten and isopimpinellin were detected in 14 root oils. Isobergapten was the second most abundant FC in 12 root oils (0.08-0.24 mg/mL), and bergapten in $H$. pyrenaicum subsp. pollinianum (from Mt Galičica) root oil $(0.18 \mathrm{mg} / \mathrm{mL})$. Isopimpinellin was always present in quantity bellow LOQ. Among all investigated Heracleum essential oils, those of the roots contained the highest amounts of total FCs equivalent to 8-MOP $(0.29-0.77 \mathrm{mg} / \mathrm{mL})$. According to current recommendations, daily intake of these essential oils, not considered to contribute significantly to overall risk, ranged from $1.94 \mathrm{~mL}$ to $5.23 \mathrm{~mL}$, and daily intake, not considered to pose any unacceptable risk, ranged from 0.02 to $0.05 \mathrm{~mL}$.

\section{Fruit essential oils}

Except in one sample of $H$. verticillatum fruit essential oil (which contained 0.16 $\mathrm{mg} / \mathrm{mL}$ of pimpinellin), in remaining 13 analyzed fruit oils FCs were present in quantities bellow LOQ. Bergapten was not detected only in one of the 14 fruit oils, and in six of them it was the only detected FC. The sum of FCs equivalent to 8-MOP in fruit oils was in the range $0.10-0.29 \mathrm{mg} / \mathrm{mL}$, and consequently, their daily intakes not considered to contribute significantly to overall risk $(5.23-15.68 \mathrm{~mL})$ and to pose any unacceptable risk (0.05-0.16 mL), were higher compared to root essential oils.

\section{Leaf and flower essential oils}

Heracleum montanum flower oil contained only pimpinellin ( $<$ LOQ), and $H$. pyrenaicum subsp. pollinianum leaf oil only bergapten $(0.07 \mathrm{mg} / \mathrm{mL})$. On the other hand, $H$. verticillatum leaf oil, besides these two FCs also contained isobergapten, and had $0.52 \mathrm{mg} / \mathrm{mL}$ of total FCs equivalent to 8-MOP. Daily intakes of $H$. verticillatum leaf oil not considered to contribute significantly to overall risk and to pose any unacceptable risk were 2.90 and $0.03 \mathrm{~mL}$, and of both $H$. pyrenaicum subsp. pollinianum leaf and $H$. montanum flower oils were 15.68 and $0.16 \mathrm{~mL}$.

\section{Discussion}

Despite widespread opinion that medicinal products originating from plants are safe, some of them can contain various constituents of toxicological concern. Such substances include e.g. estragole in basil herb, Basilici herba, bitter/sweet fennel, Foeniculi amari/dulcis fructus and aniseed, Anisi fructus, thujone in sage leaf, Salviae officinalis folium and wormwood herb, Absinthii herba, and pyrrolizidine alkaloids in comfrey root, Symphyti radix, as well as FCs in angelica root, Angelicae archangelicae 
radix. For these compounds, EMA/HMPC established maximum daily intakes $(15,18-$ 20).

In reflection paper on the risks associated with FCs contained in preparations of angelica, limits of daily intake of FCs (through herbal medicinal products) based on two different approaches were suggested. The first approach is based on average dietary exposure to FCs, which is $1.45 \mathrm{mg}$ (as mentioned before, FCs are normally present in certain quantities in some vegetables from the Apiaceae family and fruits from the Rutaceae family). An additional daily intake of $1.5 \mathrm{mg}$ through herbal medicinal products is not considered to contribute significantly to overall risk, since phototoxic reactions can be expected after intake of more than 14-15 mg FCs, in the presence of UV irradiation. This scenario can occur for example after consumption of some wild plants, because cultivated vegetables and fruits usually contain lower amounts of FCs $(13,15,21)$. The second approach is based on the thresholds for toxicological concern (TTC) concept, originally intended for potentially genotoxic and carcinogenic impurities of pharmaceuticals, which implies thresholds of maximally $120 \mu \mathrm{g}$ (for exposure lasting one month and less) and $1.5 \mu \mathrm{g}$ (for life-time exposure). However, based on current trends of use of herbal medicinal products and the doses of 8-MOP used in PUVA treatment, EMA/HMPC defined the daily intake margin of $15 \mu \mathrm{g}$ FCs through herbal medicinal products as the one not considered to pose any unacceptable risk. It was also suggested to express FC limits in 8-MOP equivalents, and stressed out that the calculation of the sum of FCs to be equivalent to 8-MOP may present the worstcase scenario, i.e. an extra margin of safety would be provided (15).

Since different pharmacological activities for investigated Heracleum essential oils were previously demonstrated, determination of maximum daily intake related to FCs content was necessary as the precondition for their further investigations as potential new medicinal herbal raw materials, and in general, is an example of evaluation of safety profile of herbal preparations containing FCs according to current EMA/HMPC recommendations.

\section{Acknowledgments}

This work was supported by the Ministry of Education, Science and Technological Development of the Republic of Serbia (grant number 173021). 


\section{References}

1. Skalicka-Woźniak K, Grzegorczyk A, Świątek Ł, Walasek M, Widelski J, Rajtar B, et al. Biological activity and safety profile of the essential oil from fruits of Heracleum mantegazzianum Sommier \& Levier (Apiaceae). Food Chem Toxicol. 2017 Nov;109:820-6.

2. Lesinger I. Kućna biljna ljekarna. Rijeka: Adamić; 2006. 315 p.

3. Vračarić B, Bakić J, Čolić D, Lintner V, Micković M, Rajšić R, et al. Ishrana u prirodi. Belgrade: Vojnoizdavački zavod; $1977.64 \mathrm{p}$.

4. Mandenova IP. Heracleum L. In: Schischkin BK, editor. Flora of the U.S.S.R., Vol. 17. Moscow, Leningrad: Botanical Institute of the Academy of Sciences of the USSR; 1951. p. 222-60.

5. Brummitt RK. Heracleum L. In: Tutin TG, Heywood VH, Burges NA, Moore DM, Valentine DH, Walters SM, Webb DA, editors. Flora Europaea, Vol. 2. London: Cambridge University Press; 1968. p. 364-6.

6. Ušjak L, Petrović S, Drobac M, Soković M, Stanojković T, Ćirić A, Niketić M. Chemical composition and bioactivity of the essential oils of Heracleum pyrenaicum subsp. pollinianum and Heracleum orphanidis. Nat Prod Commun. 2016 Apr;11(4):529-34.

7. Ušjak L, Petrović S, Drobac M, Soković M, Stanojković T, Cirić A, et al. Chemical composition, antimicrobial and cytotoxic activity of Heracleum verticillatum Pančić and H. ternatum Velen. (Apiaceae) essential oils. Chem Biodiversity. 2016 Mar;13(4):466-76.

8. Ušjak L, Petrović S, Drobac M, Soković M, Stanojković T, Ćirić A, Niketić M. Essential oils of three cow parsnips - composition and activity against nosocomial and foodborne pathogens and food contaminants. Food Funct. 2017;8(1):278-90.

9. Ušjak L, Petrović S, Drobac M, Soković M, Stanojković T, Ćirić A, Niketić M. Edible wild plant Heracleum pyrenaicum subsp. orsinii as a potential new source of bioactive essential oils. J Food Sci Technol. 2017 Jul;54(8):2193-202.

10. Ušjak L, Petrović S, Drobac M, Niketić M. DPPH scavenging activity of the fruit essential oils of six Heracleum L. taxa (Apiaceae). Book of Abstracts of 2nd International Conference on Natural Products Utilization: from Plants to Pharmacy Shelf (ICNPU-2015); 2015 Oct 14-17; Plovdiv, Bulgaria; $314 \mathrm{p}$.

11. Ušjak L, Drobac M, Niketić M, Petrović S. DPPH radical scavenging potential of the root essential oils of five Heracleum L. taxa. Book of Abstracts of 7th Balkan Botanical Congress (7BBC 2018); 2018 Sep 10-14; Novi Sad, Serbia; 131 p. (Botanica Serbica; Vol. 42, suppl. 1).

12. Ušjak L, Drobac M, Niketić M, Petrović S. Chemosystematic significance of essential oil constituents and furanocoumarins of underground parts and fruits of nine Heracleum L. taxa from Southeastern Europe. Chem Biodiversity. 2018 Dec;15(12):e1800412.

13. Peroutka R, Schulzová V, Botek P, Hajšlová J. Analysis of furanocoumarins in vegetables (Apiaceae) and citrus fruits (Rutaceae). J Sci Food Agric. 2007 Jun;87(11):2152-63.

14. Vogl S, Zehl M, Picker P, Urban E, Wawrosch C, Reznicek G, et al. Identification and quantification of coumarins in Peucedanum ostruthium (L.) Koch by HPLC-DAD and HPLCDAD-MS. J Agric Food Chem. 2011 Mar;59(9):4371-7. 
15. European Medicines Agency. EMA/HMPC/317913/2006. Reflection paper on the risks associated with furocoumarins contained in preparations of Angelica archangelica L. London: 31 October 2007.

16. Hannuksela-Svahn A, Pukkala E, Läärä E, Poikolainen K, Karvonen J. Psoriasis, its treatment, and cancer in a cohort of Finnish patients. J Invest Dermatol. 2000 Mar;114(3):587-90.

17. International Conference on Harmonisation (ICH). ICH harmonised tripartite guideline. Validation of analytical procedures: text and methodology Q2 (R1). Geneva: ICH, 2005.

18. European Medicines Agency. EMEA/HMPC/137212/2005. Public statement on the use of herbal medicinal products containing estragole. London: 23 November 2005.

19. European Medicines Agency. EMA/HMPC/732886/2010 Rev.1. Public statement on the use of herbal medicinal products containing thujone. London: 22 May 2012.

20. European Medicines Agency. EMA/HMPC/893108/2011. Public statement on the use of herbal medicinal products containing toxic, unsaturated pyrrolizidine alkaloids (PAs). London: 24 November 2014.

21. DFG-SKLM. Toxikologische Beurteilung von Furocumarinen in Lebensmitteln. In: Eisenbrand G, editor. Lebensmittel und Gesundheit II. Sammlung der Beschlüsse und Stellungnahmen/Opinions (1997-2004). Weinheim: Wiley-VCH; 2005. p. 55-87. 


\title{
Procena bezbednosnog profila etarskih ulja osam taksona roda Heracleum (Apiaceae) u odnosu na utvrđeni sadržaj furanokumarina
}

\author{
Ljuboš Ušjak $^{1 *}$, Milica Drobac ${ }^{1}$, Marjan Niketić ${ }^{2}$, Silvana Petrović ${ }^{1}$ \\ ${ }^{1}$ Univerzitet u Beogradu - Farmaceutski fakultet, Katedra za farmakognoziju, Vojvode \\ Stepe 450, 11221 Beograd, Srbija \\ ${ }^{2}$ Prirodnjački muzej, Njegoševa 51, 11000 Beograd, Srbija \\ *Autor za korespondenciju: Ljuboš Ušjak Tel.: +381 1139513 22; \\ e-mail: ljubos@pharmacy.bg.ac.rs
}

\section{Kratak sadržaj}

$\mathrm{Za}$ etarska ulja korena, listova, cvasti i plodova osam taksona roda Heracleum (H. sphondylium, H. sibiricum, H. montanum, H. ternatum, H. pyrenaicum subsp. pollinianum, $H$. pyrenaicum subsp. orsinii, $H$. verticillatum i $H$. orphanidis) prethodno su pokazane antimikrobna, citotoksična (selektivna prema tumorskim ćelijama) i/ili antioksidantna aktivnost. Cilj ovog rada bio je da se ustanovi maksimalni dozvoljeni dnevni unos etarskih ulja u odnosu na utvrđeni sadržaj ukupnih furanokumarina, u skladu sa preporukama Komiteta za biljne lekovite proizvode Evropske agencije za lekove (EMA/HMPC). Furanokumarini su kvantifikovani gasnom hromatografijom i njihov ukupni sadržaj izražen je kao ksantotoksin (8metoksipsoralen, 8-MOP). Dnevni unos ispitivanih etarskih ulja koji ne doprinosi značajno ukupnom riziku (ekvivalentan unosu 1,5 mg furanokumarina izraženih kao 8-MOP), kreće se u opsegu 1,94-5,23 mL za etarska ulja korena, 5,23-15,68 mL za ulja plodova i 2,90-15,68 mL za ulja listova ili cvasti. Dnevni unos etarskih ulja koji ne predstavlja nikakav rizik (ekvivalentan unosu $15 \mu \mathrm{g}$ furanokumarina izraženih kao 8-MOP), kreće se u opsegu 0,02-0,05 mL za etarska ulja korena, $0,05-0,16 \mathrm{~mL}$ za ulja plodova i $0,03-0,16 \mathrm{~mL}$ za ulja listova ili cvasti. Ovaj rad demonstrira primenu aktuelnih EMA/HMPC preporuka u cilju utvrđivanja bezbednosnog profila biljnih preparata u kojima su detektovani furanokumarini.

Ključne reči: Heracleum, etarska ulja, furanokumarini, 8-MOP, bezbednosni profil 